\title{
Desenvolvimento local e estratégia de pequenos empreendimentos agroindustriais - a lógica da cooperação e do associativismo: o Pacto Fonte Nova
}

\author{
Local development and strategy of small agribusiness enterprises - the logic of \\ cooperation and association: the "Fonte Nova" Agreement
}

\author{
Jorge Oneide Sausen ${ }^{1}$ \\ Ivete Aparecida Patias ${ }^{2}$ \\ Sérgio Luís Allebrandt ${ }^{3}$
}

\section{Resumo}

Estudo sobre o empreendimento Pacto Fonte Nova, uma organização associativa articulada em torno de um projeto de desenvolvimento local, instituído por meio de um trabalho de cooperação entre o poder público local, lideranças estratégicas do município de Crissiumal-RS e forças produtivas daquela localidade. $\mathrm{O}$ objetivo do estudo consistiu em analisar e compreender o processo de criação e desenvolvimento deste empreendimento e as relações dele com o processo de desenvolvimento local e regional. A análise realizada foi fundamentada por uma premissa metodológica orientadora de pesquisa, a abordagem longitudinal, histórica e contextual, que procura entender o processo evolutivo de estruturação e mudança de uma organização, considerando-se três elementos fundamentais: o conteúdo da mudança; o seu contexto da mesma; e seu processo de implementação. Enquadra-se, portanto, na classificação de pesquisa qualitativa. Os resultados revelam que o Pacto Fonte Nova foi uma iniciativa interessante de desenvolvimento local, uma vez que instituiu um processo de articulação das lideranças e das forças econômicas e políticas de um município que se encontrava num estágio de estagnação econômica e de inércia em termos de alternativas que pudessem reverter o quadro de descrédito e desânimo da população. Contudo aquele que foi um importante projeto de revitalização do desenvolvimento local, e que proporcionou uma nova dinâmica de entendimento dos agentes políticos e econômicos do município, também apresentou uma série de problemas e entraves a um resultado ainda mais expressivo dessa iniciativa de desenvolvimento concebida de uma ação centrada no propósito da cooperação, da solidariedade e do associativismo.

Palavras-chave: Desenvolvimento local. Estratégias coletivas. Cooperação. Empreendimentos agroindustriais.

Artigo submetido em 16 de março de 2011 e aceito para publicação em 04 de agosto de 2011.

${ }^{1}$ Doutor em engenharia da produção pela UFSC; Professor titular da UNIJUI. Endereço: Programa de Mestrado em Desenvolvimento. Endereço: Rua do Comércio, 3000, Bairro Universitário, CEP 98700-000, ljuí, Rio Grande do Sul, Brasil. E-mail: josausen@unijui.edu.br

2 Mestre em desenvolvimento pela UNIJUI; Professora da FEMA. Endereço: Rua Almirante Cabral, 245, Centro, CEP 98940-000, Tuparendi, Rio Grande do Sul, Brasil. E-mail: ivetepatias@terra.com.br

3 Doutor em desenvolvimento regional pela UNISC; Professor titular da UNIJUI. Endereço: Programa de Mestrado em Desenvolvimento. Endereço: Rua do Comércio, 3000, Bairro Universitário, CEP 98700-000, ljuí, Rio Grande do Sul, Brasil. E-mail: allebr@unijui.edu.br 


\begin{abstract}
This study is about the Fonte Nova enterprise, which is an associative organization linked to a local development project instituted from a cooperative work involving the local government, strategic leadership of the city of Criciumal-RS and the productive forces of this local. The objective of this study is to analyze and understand the process of creation and development of this enterprise and the relationships between this project and the local and regional process of development. The analysis was based on a methodological research guideline - the longitudinal, historical and contextual approach - which seeks to understand the evolutionary process of structuration and change of an organization, considering three fundamental elements: the contents of change, its context and its implementation process. Thus, this is a qualitative study. The results reveal that the Fonte Nova agreement was an interesting initiative of local development, since it instituted a process of articulation between the leaderships and the economical and political forces of a city that was economically stagnant and inert, concerning alternatives that could reverse the incredulity and prostration that was commonplace among the population. However, this agreement, which was an important project to revitalize local development and which allowed a new dynamic of agreement between the political and economical agents of the city, also presented a number of problems and obstacles that prevented an even more expressive result of this initiative of development, conceived from an action centered on the purpose of cooperation, solidarity and association.
\end{abstract}

Keywords: Local development. Collective strategies. Cooperation. Agribusiness enterprises.

\title{
Introdução
}

A mudança aparece como uma das principais características do mundo contemporâneo - não só como inevitável, mas necessária à sobrevivência das pessoas e organizações.

Em nenhum momento da história, a sociedade passou por tantas transformações como neste último século. O trabalho e a força de trabalho, a sociedade e a forma de governo são, nestas últimas décadas, totalmente diferentes de tudo que existiu em qualquer outro momento.

Essa avassaladora onda de mudanças espalha-se por todos os cantos, em uma progressão cada vez mais acelerada. As organizações se encontram no meio dessas ondas. A turbulência e imprevisibilidade do ambiente impõem às organizações a necessidade de constantes ajustes e adaptações em seus processos de gestão e em suas estratégias organizacionais para responderem de forma mais eficaz a esse novo contexto.

A gestão das mudanças organizacionais, seja ela ligada aos aspectos do reposicionamento estratégico para melhor competir no mercado ou às estratégias empresariais de legitimar as organizações na sociedade, no que tange aos compromissos de responsabilidade social que a sociedade exige destas, envolve a coesão de múltiplos esforços de gestão na busca de melhores níveis de performance organizacional, como também de ações de relacionamentos interorganizacionais para a promoção de um desenvolvimento que concilie, de forma sustentável, objetivos econômicos, sociais e ambientais.

Nesse contexto, o Grupo de Pesquisa Competitividade, Mudança Estratégica e Alinhamento Organizacional para o Desenvolvimento (GPCOM), do Programa de Mestrado em Desenvolvimento da Universidade Regional do Noroeste do Estado do Rio Grande do Sul (Unijuí), vem estudando, há mais tempo, o modo como as organizações da região processam suas mudanças e como desenvolvem suas estratégias competitivas para enfrentar os desafios que o mercado impõe, tendo como foco de análise um conjunto de organizações de pequeno, médio e grande porte desta região do estado, que tem influência na dinâmica do desenvolvimento da região.

Esses estudos focam especialmente a influência do contexto externo nas ações de reposicionamento estratégico e performance dessas organizações, bem como o papel e a influência dessas ações empresariais no processo de desenvolvimento da região. Suas contribuições podem ser entendidas de duas perspectivas de 
análise: 1) as investigações se justificam pela possibilidade de construção de análises teóricas explicar a complexa relação dos processos de mudança e adaptação estratégica de organizações que desenvolvem suas atividades num entorno territorial com características próprias, diferentemente de outras regiões do estado e país; 2) os estudos também envolvem a análise do modo como as organizações pesquisadas contribuem para o desenvolvimento da região a que pertencem.

Parte-se do princípio da ideia da superação de uma concepção de gestão que tem dado ênfase somente na busca da eficiência e da eficácia organizacionais. A exagerada ênfase nesses conceitos tem restringido a consecução de objetivos ao desenvolvimento num sentido mais amplo.

Agrega-se, na análise deste estudo, o conceito de efetividade organizacional, que significa o alcance de objetivos do desenvolvimento econômico-social. Trabalha-se com o conceito da gestão para o desenvolvimento (MOTTA, 1985). A efetividade da gestão vai além do conceito de eficácia, restrito a objetivos organizacionais, que, apesar de essenciais ao sucesso dos empreendimentos, não são suficientes por si só. Efetividade se refere a objetivos de comprometimento mais amplo com um desenvolvimento mais harmonioso do ponto de vista econômico, social e ambiental.

Almejar apenas os resultados em termos de eficiência e eficácia nas organizações significa, geralmente, criar grupos fortes e estáveis, mas que não promovem, com maior ênfase, os objetivos do desenvolvimento econômico-social (MOTTA, 1985).

A gestão das organizações, dessa perspectiva, passa a ser vista do enfoque de diferentes racionalidades: econômica, substantiva, comunicativa e dialógica (GUERREIRO RAMOS, 1981; HABERMAS, 1989; TENÓRIO, 2004). Advoga-se, aqui, uma relação de complementaridade entre estas racionalidades e não uma contradição.

Trata-se da defesa de uma concepção de gestão que necessita, ao mesmo tempo, responder aos imperativos de uma boa performance organizacional - em termos de resultados econômicos que viabilizem o sucesso dos empreendimentos e os tornem mais competitivos no mercado - e estar comprometida com os objetivos do desenvolvimento das comunidades em que estas organizações se inserem.

Mister se faz também considerar uma visão ampla e sistêmica de desenvolvimento. É necessário entendê-lo como um processo que contempla uma abordagem de uma perspectiva histórica e multidimensional, envolvendo aspectos de ordem econômica, social, organizacional, ambiental, cultural, tecnológica, humana, política e ética.

Nessa linha de entendimento, Tenório (2007, p. 17) tem afirmado que:

Pensar o desenvolvimento local requer o envolvimento de diversas dimensões: econômica, social, cultural, ambiental e físico-cultural, político-institucional e científico-tecnológica. Implica considerar os diferentes aspectos de inter-relacionamento ativo dos diversos atores da sociedade. Nesse sentido importa, necessariamente, uma profunda transformação das relações sociais - não apenas dos processos gerenciais e técnicos de produção - incluindo também a preservação ambiental, posto que a incorporação dessa dimensão às estratégias, programas e projetos de desenvolvimento tem como objetivo assegurar melhores condições materiais e a sustentabilidade do território, segundo as suas condições e vocações.

O estudo aqui apresentado aparece no contexto da discussão dessa problemática de pesquisa, cujos trabalhos procuram compreender como as organizações da região se inserem no processo de desenvolvimento regional, baseando-se no entendimento das relações que se estabelecem entre os diversos agentes econômicos, das influências destes na dinâmica produtiva regional e das estratégias e modelos de gestão estabelecidos no âmbito destas organizações. 
Assim, a pesquisa envolveu o estudo do empreendimento Pacto Fonte Nova, uma organização associativa, articulada em torno de um projeto de desenvolvimento local, com origem em um trabalho de cooperação entre o poder público local, as lideranças estratégicas do município e as forças produtivas daquela localidade - Crissiumal-RS.

O objetivo do estudo, portanto, consistiu em analisar e compreender o processo de criação e desenvolvimento do Pacto Fonte Nova e as relações deste empreendimento com o desenvolvimento local e regional. Mais especificamente, pretendeu-se descrever o processo de criação e evolução do Pacto, com base na sua estruturação e no seu posicionamento no mercado, na condição de modo de produção associativo; analisar e compreender a dinâmica utilizada pelo empreendimento, seus processos de concepção e implementação das estratégias organizacionais que definiram a forma de sobrevivência e competição das pequenas agroindustriais integrantes do projeto; e, por fim, avaliar a efetiva contribuição no processo de desenvolvimento local da sua região de inserção, observando o impacto socioeconômico proporcionado mediante percepções dos agentes envolvidos.

\section{Abordagem Metodológica do Estudo}

\section{Classificação da pesquisa}

Este estudo enquadra-se na classificação de pesquisa qualitativa, na medida em que procurou constituir a história do programa de desenvolvimento local Pacto Fonte Nova, por intermédio das falas dos seus atores, ou seja, das pessoas que participaram da concepção da ideia inicial, dos articuladores deste projeto, como também das lideranças políticas do município e dos pequenos empresários rurais que integram o Pacto.

Merriam (1998) aponta um conjunto de cinco características que considera essenciais para configurar formas de pesquisa qualitativa. A primeira refere-se a uma suposição filosófica chave: todos os tipos de pesquisa qualitativa são baseados na visão de que a realidade é construída por indivíduos que interagem com seus mundos sociais. Dessa forma, os pesquisadores envolvidos estão interessados em entender os significados construídos pelas pessoas, isto é, como estas dão sentido aos seus mundos e às experiências que tiveram nele. Uma segunda característica está em que o pesquisador constitui um instrumento primário para a coleta e análise dos dados. A terceira indica que a pesquisa qualitativa envolve trabalho de campo para observar comportamentos. O emprego de uma estratégia indutiva de pesquisa apresenta-se como uma quarta característica importante. E, finalmente, este enfoque de pesquisa é ricamente descritivo.

No contexto da abordagem qualitativa, o estudo exigiu, também, um trabalho de detetive (MINTZBERG, 1997), buscando, de forma indutiva, construir e descrever a história desse movimento que apresentou não apenas uma alternativa de desenvolvimento local, mas evidenciou uma série de problemas, fruto das dificuldades de levar adiante uma proposta de ação que tem na cooperação e no espírito de solidariedade a sua estratégia de sobrevivência e crescimento.

\section{Procedimentos de coleta e análise de dados}

Nesta pesquisa qualitativa, procurou-se entender como o Pacto Fonte Nova se estruturou e se organizou ao longo do seu período de existência, na condição de um programa de desenvolvimento local com um conjunto de estratégias de sobrevivência e crescimento para as pequenas agroindústrias no município de Crissiumal. Desse modo, os procedimentos de coleta de dados foram pautados por entrevistas com 13 representantes das entidades coordenadoras e executoras do programa, dos quais 04 eram representantes do poder público (exprefeito, vice-prefeito, secretário municipal do meio ambiente e funcionário da Secretaria Municipal da 
Agricultura); com 06 gestores de entidades estratégicas do município (ex-presidente, ex-gerente e gerente da Cooper Fonte Nova, presidente da Associação Comercial e Industrial de Crissiumal, presidente do Sindicato dos Trabalhadores Rurais e gerente da Sicredi); e 03 funcionários que desempenhavam funções destacadas na coordenação das atividades do Pacto (nutricionista, ex-secretária da Cooper Fonte Nova e extensionista da EMATER). Também foram entrevistados 16 proprietários/gestores das agroindústrias, representando 14 agroindústrias, ou seja, 46,66\% do universo de 30 agroindústrias constituintes do Pacto, sendo 14 proprietários e 02 gerentes.

Nesse contexto, os procedimentos de coleta e análise de dados foram estruturados com base em uma premissa metodológica orientadora, a abordagem longitudinal/histórica e contextual (PETTIGREW, FERLIE e MCKEE, 1992). Esta abordagem procura entender o processo evolutivo de estruturação e mudança de uma organização tendo por base três elementos fundamentais: o conteúdo da mudança (o que); o contexto da mudança (por que); e o processo da mudança (como).

O conteúdo refere-se a um conjunto de ações e/ou estratégias que dão consistência a uma determinada decisão. O contexto é o elemento que serve de justificativa à opção por uma determinada estratégia ou decisão. O processo, por sua vez, refere-se ao modo como estratégia ou decisão foi desenvolvida.

Em termos gerais, "o que" aconteceu diz respeito ao conteúdo, à estratégia propriamente dita; o "por que" origina-se de uma análise do contexto, das razões que justificam essa estratégia; e o "como" pode ser entendido pelo modo como essa estratégia foi colocada em prática, a sua processualidade.

A abordagem longitudinal/histórica e contextual (Pettigrew, Ferlie e McKee, 1992) estabelece um tipo de análise holística e dinâmica do processo de mudança estratégica. Parte do pressuposto de que, para entender as origens, o desenvolvimento e a implantação de uma mudança estratégica, é preciso utilizar-se de um referencial que contemple a multiplicidade dos níveis de análise. O ponto de partida é a noção de que formular o conteúdo de qualquer nova estratégia inevitavelmente requer o gerenciamento do seu contexto e processo.

O Pacto Fonte Nova foi um programa de ação cooperada entre várias organizações que promoveu uma mudança estratégica no processo de desenvolvimento local. Procurou-se, então, entender no que efetivamente se constituiu o Pacto Fonte Nova, ou seja, quais as ações estratégicas concebidas pelas lideranças locais que deram consistência a este programa de desenvolvimento local e sustentabilidade às pequenas agroindústrias integrantes (conteúdo da mudança estratégica); quais os fatores e razões que justificaram a adoção de decisões e estratégias em torno da gestão do Pacto e, consequentemente, das agroindústrias que o integravam (contexto que levou à adoção das decisões e estratégias); e como se deu o desenvolvimento dessas ações estratégicas que determinaram uma efetiva contribuição no processo de desenvolvimento local, em virtude de uma grande mudança estratégica gestada de forma cooperada e associativa num determinado território (processo de implementação e efetividade da ação).

O Processo de Articulação e Organização do Programa de Desenvolvimento Local: Pacto Fonte Nova

\section{Dos motivos da busca de uma nova alternativa de desenvolvimento local}

O município de Crissiumal está situado na região noroeste do Estado do Rio Grande do Sul, integra a microrregião Celeiro, da qual participam 21 municípios que, em sua grande maioria, têm a economia atrelada à produção agropecuária de pequenas propriedades rurais com pouca industrialização. A população do município é de 14.726 habitantes, de acordo com o Censo 2007 (IBGE, 2010a), e praticamente $60 \%$ dela vivem na área rural. 
Em um cenário de políticas agrícolas definidas pelo governo federal, com incentivo à monocultura de soja, as pessoas migraram do município para os grandes centros, resultando no êxodo rural, consequência das frustrações de safra, do fim dos subsídios agrícolas e da política de preços não compensatórios aos custos de produção.

Na década de 1990 a população do Rio Grande do Sul cresceu 11,48 \% e, no mesmo período, a região Celeiro diminuiu em 13,1\% sua população (PACTO FONTE NOVA, 2007).

Além disso, a população de Crissiumal tinha mais um fator para estar descontente com os governantes: o município não tinha acesso por meio de asfalto e os $27 \mathrm{~km}$ que ligavam o município até a BR 468 estavam em obras havia 23 anos. Em 1997, ocorreu um movimento por parte da população chamado "Sem asfalto, sem voto". A população foi às urnas e votou em branco para deputado estadual devido à falta de continuidade de ações e à baixa destinação de recursos do estado. Nesse momento, a população "cruzou os braços", entendendo que nem o estado e nem mesmo a União resolveriam os problemas locais. Tinham, contudo, a consciência de que era preciso pensar uma alternativa de desenvolvimento.

\section{Dos objetivos da iniciativa}

Diante desse cenário, o poder público e as entidades estratégicas do município organizaram-se para formar um programa que diversificasse a produção, agregando renda aos pequenos produtores rurais, numa perspectiva associativa e de responsabilidade socioambiental. Surge, então, em 1998, o programa denominado "Pacto Fonte Nova".

No município estava em andamento o Programa Via Lácteo, criado pela Lei Municipal 1.395/97, de 22 de agosto de 1997, que consistiu na primeira iniciativa de diversificar a produção e promover a inclusão social. Este programa baseava-se em estimular a produção leiteira do município, com o apoio do Serviço Brasileiro de Apoio às Micro e Pequenas Empresas (Sebrae), por intermédio do Programa de Desenvolvimento Rural (Poder). Este empreendimento impulsionou a produção de leite no município e teve grande importância para o surgimento do Pacto Fonte Nova.

A proposta do Programa Pacto Fonte Nova era de abranger outros segmentos para além do segmento leite. Nesse aspecto, o poder público manteve contato com entidades como a Empresa Brasileira de Pesquisa Agropecuária (Embrapa), do Estado de Santa Catarina, e a Empresa de Assistência Técnica e Extensão Rural (Emater), dos estados do Rio Grande do Sul e Paraná, em busca dos principais programas ou projetos de desenvolvimento na área rural nestes estados. Foram realizadas visitas, por parte do poder público (viceprefeito da época, Sr. Walter Luiz Heck) e alguns agrônomos da prefeitura, para conhecer experiências das cidades de São Miguel do Oeste e São José do Cedro, em Santa Catarina, e em várias outras cidades do Paraná, entre elas Toledo, Chopinzinho e Dois Vizinhos, que possuíam iniciativas associativas de empreendimentos econômicos. Os mesmos concluíram que a região integrada pelos municípios de Pato Branco e Francisco Beltrão, no sudoeste do Paraná, tinha o que procuravam. Nessa região estava em andamento o Programa Pacto Nova Itália, com a união, no início, de 40 municípios, que buscaram uma consultoria italiana para tentar reproduzir o modelo de desenvolvimento da Terceira Itália, da região de Vêneto, na Itália. Com essa descoberta, o poder público de Crissiumal organizou uma excursão, mobilizando 21 prefeitos de municípios da Região Celeiro para conhecerem essa experiência no sudoeste do Paraná.

Depois da visita à região do Pacto Nova Itália, iniciou-se a mobilização em torno de um pacto na Região Celeiro.

O programa tinha como perspectiva atingir toda a região. Foram realizadas reuniões da associação dos municípios, mas, por questões políticas, como a decisão sobre o município sede do programa, a ideia não foi adiante. Com esse impasse, o programa adquiriu uma dimensão microrregional, sendo integrado pelos 
municípios de Crissiumal, Humaitá, Nova Candelária e Tiradentes do Sul (RS) devido às suas identidades e proximidades.

O município de Humaitá teve problemas de desentendimento entre o Poder Legislativo e o Executivo, de modo que o projeto de lei elaborado pelo prefeito não foi aprovado pela Câmara Municipal. O município de Nova Candelária destinou o foco à suinocultura e se especializou nesta área. Já em Tiradentes do Sul, o poder público não teve o entusiasmo necessário para desencadear o projeto.

Mesmo sem o apoio dos municípios vizinhos, a população e as lideranças de Crissiumal resolveram levar adiante a ideia do projeto.

Em 30 de janeiro de 1998 foi promulgada a Lei Municipal $n^{\circ}$ 1.433/98, que cria o Programa de Fortalecimento Agroindustrial Pacto Fonte Nova. Algumas circunstâncias foram decisivas para a implementação dessa iniciativa de desenvolvimento local, a partir de uma estratégia coletiva.

Duas ações foram decisivas para impulsionar o desenvolvimento do programa. A primeira delas, conforme mencionado anteriormente, foi a realização de viagens organizadas pela prefeitura, em outubro de 1998, das lideranças locais, para conhecerem experiências em outros estados. A segunda foi a realização de uma pesquisa sobre a dependência de alimentos no município, em novembro de 1998, por iniciativa da Emater, executada pelos alunos do ensino médio de uma escola estadual do município. Esse estudo consistiu em investigar a origem dos alimentos e os valores que a população exportava anualmente ao adquirir produtos de outras localidades. Fazia parte da pesquisa uma lista de 84 alimentos e bebidas, pesquisados em 24 estabelecimentos comerciais, entre eles mercados, supermercados, padarias e mercadinhos. Essa pesquisa envolveu os estudantes e a professora da disciplina de Estatística da referida escola. O resultado mostrou que 75 produtos eram adquiridos de outros locais, entre eles frango, feijão, aguardente, alho, lácteos, defumados, conservas e bolachas.

Em dezembro de 1998, foi realizado o Primeiro Seminário de Alternativas para Agricultura Familiar, com o objetivo de constituir um acordo entre as entidades ${ }^{4}$ para que as mesmas assumissem o programa, de modo que ele não ficasse somente sob a responsabilidade do poder público. Nesse seminário foram apresentados os resultados da pesquisa dos alunos da escola. Foi útil, sobretudo, para a conscientização e mobilização dos produtores quanto à necessidade da diversificação da produção e importância da agroindustrialização, envolvendo cerca de 500 produtores rurais.

Em seguida foram promovidas viagens dos produtores, para que conhecessem novas experiências, à cidade de Santo Antônio da Patrulha (RS) - contato com os produtores de cana-de-açúcar - e à Teotônia (RS) produtores de leite - entre outras. Ao mesmo tempo foram desenvolvidas palestras e cursos para os produtores, com o objetivo de qualificá-los em termos de novas culturas, bem como de resgatar o espírito de associativismo e parcerias na produção rural.

O Pacto começou com 4 agroindústrias: uma indústria de laticínios, uma de vinho colonial, uma de carnes e uma fábrica de vassouras. Em 1999 esse número aumentou para 14. Em 2000, atingiu 21 empreendimentos e, até o final de 2009, totalizava 30.

A busca constante por qualificação foi demonstrada com a criação da marca Fonte Nova (Selo de Qualidade), instituída em outubro de 1998 com o objetivo de facilitar a identificação dos produtos e, ao

\footnotetext{
4 Prefeitura de Crissiumal, Cooperativa Tritícola Mista Alto Uruguai Ltda. (Cotrimaio), Cooperativa Mista Tritícola de Campo Novo Ltda. (Cotricampo), Associação Comercial e Industrial (ACl), Sindicato dos Trabalhadores Rurais, Empresa de Assistência Técnica e Extensão Rural (Emater), Sindicato dos Empregadores Rurais, Cooperativa de Técnicos da Região Noroeste do Estado do Rio Grande do Sul (Unitec), Associação de Desenvolvimento Comunitário de Crissiumal (Adesco) e Conselho Municipal de Desenvolvimento Econômico e Social.
} 
mesmo tempo, assegurar a qualidade ao consumidor, tornando-os mais competitivos e reconhecidos no comércio local e regional.

\section{Das entidades participantes}

Entre os organizadores do Programa, o poder público (prefeitura) foi o principal incentivador da iniciativa. Participou apoiando cada empreendimento com material de construção e oferecendo apoio técnico necessário ao desenvolvimento da agroindústria, dos seguintes profissionais: agrônomos, médicos veterinários, técnicos agrícolas, além de nutricionistas e vigilantes sanitários da Secretaria Municipal de Agricultura. Além do poder público, fizeram parte inicialmente do Pacto Fonte Nova as seguintes entidades, representadas na Figura 1: Empresa de Assistência Técnica e Extensão Rural (Emater); Secretaria Municipal da Agricultura e Meio Ambiente (prefeitura); Cooperativa de Técnicos da Região Noroeste do Estado do Rio Grande do Sul Ltda. (Unitec); Cooperativa Mista Tritícola de Campo Novo Ltda. (Cotricampo); Cooperativa Tritícola Mista Alto Uruguai Ltda. (Cotrimaio); Sindicato de Trabalhadores Rurais do Município de Crissiumal (STR); Sindicato dos Empregadores Rurais; Associação de Desenvolvimento Comunitário de Crissiumal (Adesco); Associação Comercial e Industrial (ACI); Conselho Municipal de Desenvolvimento Econômico e Social.

A Emater foi a principal parceira, com seus técnicos envolvidos desde o início do programa. Hoje continua assessorando com a equipe técnica dividida em setores para melhor atender os produtores. 
Figura 1

Entidades envolvidas no Programa Pacto Fonte Nova

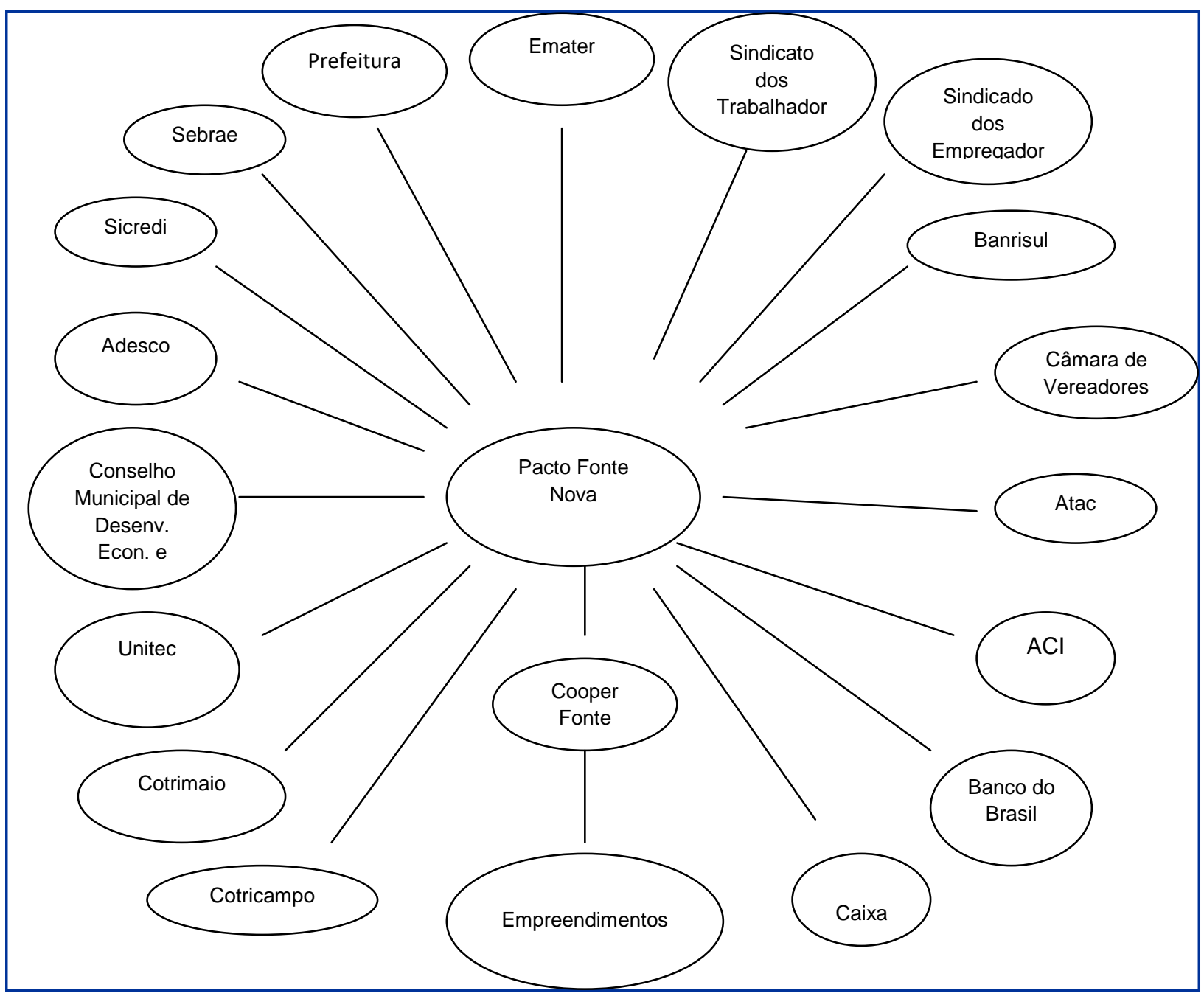

Fonte: Elaborado pelos autores.

A Secretaria Municipal de Agricultura e Meio Ambiente apoiou com um corpo técnico de dois engenheiros agrônomos, dois médicos veterinários e três técnicos agrícolas. Todos participavam ativamente como responsáveis para dar orientação às agroindústrias às quais foram designados. Os veterinários eram responsáveis pela área dos produtos de origem animal e os agrônomos e técnicos agrícolas pela área vegetal.

O Sindicato dos Empregadores Rurais organizava os cursos de orientação técnica e agroindustrial em convênio com o Serviço Nacional de Aprendizagem Rural (Senar).

O Sindicato dos Trabalhadores Rurais do Município de Crissiumal (STR) era parceiro na promoção de eventos, na assinatura de Declaração de Aptidão, via Pronaf, e na orientação sobre assegurados do INSS.

A Associação Comercial e Industrial de Crissiumal (ACI) tinha um compromisso maior, pois facilitava a inserção dos produtos do Pacto nas prateleiras dos supermercados. Foi importante também na concessão de um espaço para a sede do Pacto, no mesmo prédio da ACI, fornecendo os serviços de apoio administrativo. 
A Cooperativa de Técnicos da Região Noroeste do Estado do Rio Grande do Sul (Unitec), a Cooperativa Tritícola Mista Alto Uruguai Ltda. (Cotrimaio) e a Cooperativa Mista Tritícola de Campo Novo Ltda. (Cotricampo) prestavam orientações técnica aos agroindustriários.

O Conselho Municipal de Desenvolvimento Econômico e Social participou principalmente na instituição do projeto da merenda escolar, incluindo os produtos produzidos no âmbito do Pacto.

A Adesco disponibilizou máquinas e equipamentos de seus sócios às atividades ligadas à agricultura e pecuária, auxiliando em serviços de infraestrutura.

Depois de estruturado, outras entidades vieram a fazer parte do Pacto Fonte Nova, tais como Cooperativa de Crédito de Livre Admissão de Associados (Sicredi); Banco do Brasil; Câmara de Vereadores do Município de Crissiumal; Serviço Brasileiro de Apoio às Micro e Pequenas Empresas (Sebrae); Caixa Econômica Federal; Associação dos Técnicos Agrícolas (Atac); Banco do Estado do Rio Grande do Sul (Banrisul); Cooperativa das Atividades Agroindustriais e Artesanais do Pacto Fonte Nova Ltda. (Cooper Fonte Nova) e seus associados (agroindústrias e produtores rurais), os comerciantes e os consumidores.

Os agentes financeiros Sicredi, Banco do Brasil e Banrisul facilitaram a liberação de créditos para os agroindustriários, inovando com novas linhas de créditos, inéditas na região, uma vez que, antes da constituição do Pacto, essas entidades liberavam créditos somente para financiamentos ligados às atividades com soja, milho e leite.

A Câmara de Vereadores do Município de Crissiumal teve importante papel na busca incansável de recursos para o Pacto e na aprovação de projetos de melhoria das condições de operacionalização das atividades.

O Sebrae assumiu toda a parte de capacitação e qualificação dos produtores e agroindustriários.

Em virtude de o turismo estar se iniciando e em fase de crescimento em Crissiumal, a Caixa Econômica Federal realizou o primeiro financiamento para hotelaria, com foco no turismo rural, no contexto do movimento do Pacto.

A Associação dos Técnicos Agrícolas (Atac) assumiu toda a orientação técnica aos agroindustriários, prestando assessoria e apoio no desenvolvimento das atividades.

Em 11 de dezembro de 2002, os produtores ligados ao Pacto Fonte Nova, sentindo a necessidade de partir para uma forma de trabalho mais consistente em termos de cooperação e associativismo, criaram a Cooperativa das Atividades Agroindustriais e Artesanais do Pacto Fonte Nova Ltda., ou simplesmente Cooper Fonte Nova, que veio para consolidar o trabalho dos agricultores em forma cooperativada e fortalecer suas atividades. Foram 24 sócios fundadores que deram início a essa nova organização.

A criação da cooperativa proporcionou aos associados um importante auxílio na obtenção de inspeção sanitária, na comercialização de produtos, na aquisição em conjunto de embalagens, na colaboração em projetos, facilitando a chegada dos alimentos em escolas, creches, hospitais e restaurantes e possibilitando uma série de outros benefícios no exercício da ação associativa, de modo a maximizar os resultados na cadeia produtiva dos pequenos empreendimentos rurais.

\section{Da sua contribuição no processo de desenvolvimento local/regional}

O grupo que esteve no projeto ao longo dos mais de dez anos sempre soube distinguir o crescimento (orçamento, PIB municipal) do desenvolvimento (qualidade de vida, educação e saúde). E foi pensando em desenvolvimento que o projeto foi adiante. A diversificação de atividades que possibilitassem melhoria na renda e, consequentemente, nas condições socioeconômicas das famílias rurais, representou a tônica do 
projeto, que tinha como principal objetivo a permanência das famílias dos pequenos produtores no meio rural.

Nesse contexto, um novo projeto representava uma forma diferente de modelo de desenvolvimento, contrário ao padrão desenvolvimentista, baseado em grandes empreendimentos, concentrador de renda e excludente. A proposta de desenvolvimento primava pelo resgate das potencialidades locais mediante um enfoque endógeno, de dentro para fora.

Procurou-se, assim, mobilizar e articular a comunidade local em torno de um projeto de desenvolvimento que pudesse, por meio de um processo integrado e associativo dos agentes econômicos, criar condições de permanência das pessoas no município, sobretudo no meio rural, e reverter um processo de estagnação econômica, fruto de uma matriz produtiva que se esgotava ao longo dos últimos anos.

Sempre esteve presente, nas lideranças do Pacto, a ideia de que uma estratégia de desenvolvimento deveria contemplar as necessidades da população de modo a garantir benefícios no longo prazo, principalmente à parcela mais excluída, no caso os pequenos produtores rurais. Tal estratégia deve incluir, também, um processo integrado, que concilie objetivos econômicos, sociais e ambientais na perspectiva de um desenvolvimento sustentado.

Foram várias as ações realizadas concomitantemente para desenvolver o programa, pois as lideranças entendiam que tudo tinha de acontecer em conjunto, de forma integrada e cooperada ou nada aconteceria.

Essa iniciativa resultou nas seguintes contribuições ao desenvolvimento do município de Crissiumal.

\section{a) Agregação de renda}

Com a produção diversificada, o pequeno produtor obteve uma renda extra na comercialização dos seus produtos. Antes do programa, era extremamente dependente da produção de soja, milho e trigo. Essa renda alternativa é obtida com a comercialização dos produtos industrializados, entre eles, sucos, embutidos, conservas, rapaduras e melado.

Ao longo de dez anos, a soja, atividade principal dos agricultores, passou do primeiro para o quarto lugar, de $51 \%$ para $21,5 \%$, o que equivale a uma diminuição de $29,5 \%$ de participação no total da produção. Sobressaíram-se atividades como produção de leite, criação de suínos e plantação de fumo nos primeiros lugares na participação da produção primária.

De outro enfoque, cabe destacar que existe um aumento na procura dos produtos produzidos pelas agroindústrias devido às suas características próprias. São características nutricionais, culturais, sociais e ecológicas, que chamam a atenção do consumidor. No programa tem-se como exemplo os produtos charque suíno, polpa para suco, embutidos e queijos, que agregam um valor nutricional reconhecido pelos consumidores. Essa diferenciação é uma estratégia de inserção e ampliação do mercado consumidor, que extrapola os limites geográficos do município.

É importante destacar que o programa proporcionou a inclusão das mulheres no processo de desenvolvimento. As agroindústrias, além de aproveitarem o excedente da força de trabalho das mulheres, também levaram a que muitas assumissem a gestão dos negócios. As agroindústrias de melado, de polpa e sucos, de conservas e de bolachas são exemplos dessa situação.

A mão de obra subutilizada ou desempregada dos jovens no meio rural também foi aproveitada. O programa gerou empregos e ampliou a renda aos jovens, que até então tinham poucas alternativas. Esse aproveitamento se deu principalmente nas atividades que requeriam melhor formação técnica, como no caso dos produtores de melado e na floricultura. 
Os idosos também foram inseridos no programa, com o aproveitamento das suas experiências. Exemplo disso é o resgate de conhecimentos por parte das pessoas experientes na fabricação de alimentos, como charque suíno, biscoitos, na fabricação de bebidas como a cachaça e na produção de vassouras.

Algumas agroindústrias souberam explorar nichos de mercado, produzindo produtos mais populares para a população com renda mais baixa e, em outros casos, gerando produtos diferenciados com o objetivo de atender uma classe de consumidor de renda mais alta.

\section{b) Manutenção das pessoas no campo e melhoria na qualidade de vida}

O projeto possibilitou a permanência do produtor no meio rural de forma mais acentuada, na medida em que criou alternativas de crescimento na atividade agrícola. Como são pequenos empreendimentos, os agentes poluidores são minimizados e mais fáceis de serem tratados quando comparados aos de grandes indústrias. Assim, ocorre a manutenção das pessoas no campo sem um aumento significativo de poluentes, como nos grandes centros urbanos, onde se opta por um processo de desenvolvimento centrado em grandes empreendimentos industriais, que geram vários empregos, porém trazem consigo inúmeros problemas de poluição.

Essa estratégia de desenvolvimento, portanto, teve como um dos principais objetivos criar condições para que os pequenos produtores pudessem permanecer no campo com suas famílias, agregando renda aos seus produtos, via um processo de diversificação e industrialização da produção, mesmo que em escala pequena, mas com um significativo aumento dos ganhos da família.

O programa também conseguiu que os pequenos agricultores desenvolvessem atividades sem que se alterasse a estrutura do espaço agrário; permitiu, assim, que permanecessem no interior e melhorassem suas condições de vida. Exemplo disso é o caso de um horticultor que permaneceu com uma pequena área de terra e aumentou significativamente sua renda com a introdução de novas técnicas de manejo.

A interferência do poder público, em forma de parceria com entidades públicas e privadas, levou à melhoria de vida no campo. Incentivos - não só de créditos financeiros, mas também de valorização do trabalho rural, por meio de viagens, cursos de capacitação e seminários - possibilitaram a ampliação da visão empresarial desses produtores e, consequentemente, provocaram mudanças nas propriedades e atividades de modo a agregar valor à produção e criar condições objetivas para a manutenção das famílias no campo, evitando o êxodo rural e a marginalização das pessoas no processo de exclusão social, em virtude da falta de alternativas de trabalho no campo.

\section{c) Diversificação da produção}

Os idealizadores do programa souberam identificar muito bem as atividades econômicas rentáveis e competitivas observando as peculiaridades do local. Dessa forma, ficou facilitado o entendimento, de parte dos agricultores, para sair da monocultura, atividade que se mostra esgotada. O sucesso do programa Via Lácteo, que visava o fortalecimento da atividade leiteira, deu o passo inicial para a diversificação da produção. O produtor foi preparado tecnicamente, com cursos em sala de aula e visitas técnicas, para gerenciar melhor a atividade leiteira. Foram oferecidos incentivos aos produtores, como o fornecimento de materiais para melhorar as estruturas físicas de suas atividades. Assim, nos últimos dez anos, mais de mil produtores foram treinados e qualificados. Com isso, em 2001, Crissiumal tornou-se o maior produtor de leite do estado. Passou de uma produção de 30.000 litros/dia para 100.000 litros/dia. Os produtores fizeram investimentos como aquisição de matrizes, resfriadores e ordenhadeiras, melhorando as estruturas físicas e técnicas das propriedades. O produtor deixou de ser um mero "tirador de leite" e passou a ser um empresário do leite. 
O programa trouxe novas alternativas de negócio. Aquilo que antes era produzido apenas para consumo doméstico passou a ser explorado como alternativa de negócio. A crescente demanda por produtos ecológicos e saudáveis levou os consumidores a adquirirem produtos coloniais, criando um novo espaço e mercado por meio de uma marca própria e com um apelo de qualidade no contexto da ideia de produtos naturais.

A transformação do que é produzido pelos pequenos produtores rurais é que torna viável a pequena propriedade rural. Com a diversificação da produção foi extinta a dependência alimentar que o município tinha em relação aos produtos vindos de outros lugares, o que fortaleceu a economia local e permitiu que os resultados da comercialização ficassem no próprio município. Foi alterada a matriz produtiva e de renda do município. Antes dependente quase exclusivamente da monocultura, que sofria muita interferência das variáveis climáticas, passou a auferir rendas de outros produtos alternativos à cultura de grãos, historicamente a grande responsável pela geração de renda no município.

\section{d) Diminuição da emigração}

Nos últimos anos houve acentuada migração interna no Estado do Rio Grande do Sul e forte redução na taxa de crescimento da população, levando ao crescimento demográfico negativo de vários municípios. As estruturas fundiárias, que concentram propriedades rurais com menos de 25 hectares, têm contribuído muito para esse processo migratório da população. Quanto mais distante o município for da capital (Crissiumal está situado a $500 \mathrm{~km}$ de distância de Porto Alegre) e quanto mais agrícola é a vocação deste, menor é o crescimento da população. Essa população migrava para os grandes centros em busca de ofertas de trabalho nas indústrias que lá se concentram.

Ao agregar renda e melhorar a qualidade de vida dos produtores rurais, com a oferta de trabalho, o Pacto levou a população a permanecer no meio rural e ainda possibilitou que familiares que estavam nos grandes centros urbanos retornassem ao município. E contribuiu, ainda, para que menos pessoas migrassem para as grandes cidades.

O número de produtores rurais ativos de Crissiumal, inscritos na Secretaria da Fazenda do Rio Grande do Sul, elevou-se de 4.233, em 1997, para 5.022, em 2007. Houve um aumento de 789 produtores rurais no período de dez anos (PREFEITURA DE CRISSIUMAL, 2010). Produtores rurais ativos são todos aqueles que, durante o período de um ano, efetuaram movimentação fiscal em seus blocos de produtor, ou seja, fizeram compras ou vendas. Já os inativos são os produtores sem movimentação financeira no período. No caso analisado, o crescimento do número de produtores ativos refere-se ao período de dez anos.

Os domicílios rurais, que em 2000 totalizavam 2.608; em 2007, foram para 2.716, com um aumento de 108 domicílios rurais nesse período (INSTITUTO BRASILEIRO DE GEOGRAFIA E ESTATÍSTICA, 2010a). Crissiumal, portanto, conseguiu conter a emigração. Esse fato também se deve à revitalização da cultura local e à mudança na forma de governar: mais voltada para as pequenas propriedades.

\section{e) Divulgação do município}

O modelo de desenvolvimento de Crissiumal, por força da criação do Pacto, contribui para disseminar programas semelhantes em outros municípios, tais como o Programa de Agroindústrias de Três Passos (RS); o Programa de Agroindústrias de São Francisco de Assis (RS); e o Programa de Agroindústrias no Alegrete (RS), constituído por meio de uma associação de apicultores do Alegrete. 
Em 2010, 13 municípios do Estado do Mato Grosso iniciaram atividades com o objetivo de introduzir programas similares ao Pacto. Todos eles orientados pelo ex-prefeito Walter Luiz Heck, uma das lideranças na implantação do programa, que presta serviços à Sicredi e ao Sebrae naquele estado.

A divulgação do município, sobretudo pela repercussão desse programa de desenvolvimento local, serviu para que as autoridades estaduais e federais olhassem de forma mais cuidadosa para Crissiumal e região; tanto é que estão em andamento as obras de pavimentação da RS-305, estrada que liga Três Passos, Crissiumal e Horizontina, uma das obras mais aguardadas nos últimos anos, visto que vai beneficiar a economia do município e região de seu entorno.

A divulgação desse programa resultou em vários prêmios à prefeitura e deu visibilidade ao município em todo o país. Nos anos de 2002 e 2003, o prefeito municipal foi premiado com o prêmio Gestor Público, concedido pelo Sindicato dos Auditores de Finanças Públicas do Rio Grande do Sul (Sindaf) e Assembleia Legislativa (RS). Em 2004, o prêmio conquistado foi o de Prefeito Empreendedor, concedido pelo SebraeRS.

\section{f) Crescimento socioeconômico}

No período que compreende a criação do Pacto até os dias de hoje (1998/2010), constata-se uma significativa melhoria nos indicadores de desempenho econômico-social do município.

Destaque especial à evolução do emprego formal no município de Crissiumal, que registrou um aumento de 14,13\% nesse período (FUNDAÇÃO DE ECONOMIA E ESTATÍSTICA, 2010).

O Produto Interno Bruto (PIB), que representa todos os bens e serviços produzidos em um determinado período e é um dos índices mais utilizados para medir a atividade econômica de uma região, mostrou que, em Crissiumal, em 1997, era de $\mathrm{R} \$ 5.339,00$ (per capita); em 2002, $\mathrm{R} \$ 6.414,00$; em 2006, subiu para $\mathrm{R} \$$ 9.687,00; e, em 2007, passou para R\$ 9.589,00. Uma evolução de 79,60\% entre os anos de 1997 e 2007 (FUNDAÇÃO DE ECONOMIA E ESTATÍSTICA, 2010).

O Índice de Desenvolvimento Socioeconômico (Idese), que mostra um conjunto de indicadores sociais e econômicos envolvendo educação, renda, saúde, saneamento e domicílios, evidencia que no período de 2000 a 2006 ocorreu uma taxa de crescimento de 3,49\%, em Crissiumal, enquanto que, na região Celeiro, ${ }^{5}$ foi de $2,36 \%$ e, no Rio Grande do Sul, 1,46\%. O índice municipal ficou acima da região e do estado, demonstrando avanços em termos sociais e econômicos.

No que tange ao crescimento econômico, também os tributos municipais tiveram uma evolução (IPTU, ISSQN, ITBI, entre outros). Em 1997, o montante da arrecadação foi de R\$351.466,00. Em 2006 esses tributos foram da ordem de $\mathrm{R} \$ 960.474,00$, resultando em um aumento de 173,27\% (Unijuí, 2010).

Enfim, esses dados mostram que o crescimento econômico do município tem relação direta com os investimentos realizados no decorrer do programa.

Ocorreu uma considerável mudança nos incentivos e investimentos em torno de um programa de desenvolvimento local que procurou resgatar a vocação de uma população e a vontade política das lideranças locais, que anteriormente se encontravam adormecidas.

5 A região Celeiro é um recorte geográfico dos COREDES/RS, compreende os municípios de Barra do Guarita, Bom Progresso, Braga, Campo Novo, Chiapetta, Coronel Bicaco, Crissiumal, Derrubadas, Esperança do Sul, Humaitá, Inhacorá, Miraguaí, Redentora, Santo Augusto, São Martinho, São Valério do Sul, Sede Nova, Tenente Portela, Tiradentes do Sul, Três Passos e Vista Gaúcha. 
Os dados evidenciam um crescimento em todos os setores da economia do município. Isso reforça a tese de que um programa de desenvolvimento integrado e articulado pode transformar a economia local, criando empregos, rendas, impostos e melhoria das condições de infraestrutura e qualidade de vida num determinado espaço territorial.

\section{g) Melhoria da infraestrutura do município}

Com a criação do programa houve um aumento na arrecadação de impostos e, consequentemente, aplicação dos recursos em obras no município nas áreas de saneamento, saúde, educação, serviços sociais, habitação, em coleta de resíduos, acesso à eletricidade, melhoria das estradas e pontes, entre outros.

Os índices que mensuram o desenvolvimento do município de Crissiumal melhoraram comparando-se os anos de 2000 e 2006, período em que o programa esteve em plena execução. O índice de educação aumentou 2,28\%; de renda, 3,08\%; de saneamento e domicílios, 3,34\%; e de saúde 5,14\%. Em comparação aos municípios do Estado do Rio Grande do Sul, no campo da saúde, Crissiumal passou do 304 lugar, em 2000 , para $39^{\circ}$, em 2006. No que tange ao Idese, Crissiumal passou do $279^{\circ}$ lugar, em 2000, para o $257^{\circ}$, em 2006 (FUNDAÇÃO DE ECONOMIA E ESTATÍSTICA, 2010).

O fato de o programa existir exigiu das agroindústrias uma infraestrutura básica, o que levou o poder público a se mobilizar. Exemplo disso são as instalações das redes de água que foram proporcionadas às empresas, e acabaram por beneficiar também a população de um modo geral. Foram instaladas 42 novas redes de água em um período de oito anos.

Houve reflexos dessa iniciativa também no processamento do lixo urbano, que era depositado a céu aberto. Durante o período do Pacto, foi construída uma usina de reciclagem, que gerou aproximadamente 30 novos empregos - resultado da união de seis prefeituras para criar o Consórcio Intermunicipal de Tratamentos e Resíduos Sólidos Urbanos (Citresu), uma empresa pública formada pelos municípios de Três Passos, Crissiumal, São Martinho, Sede Nova, Campo Novo e Bom Progresso, no Rio Grande do Sul. Atualmente mais municípios fazem parte desta empresa.

\section{h) Resgate do espírito associativo}

Com o Programa Pacto Fonte Nova, o espírito associativo foi recuperado no município. Vários treinamentos foram desenvolvidos nesse processo educativo que resgatou valores até então esquecidos na comunidade. Foi implementado, por intermédio do Sicredi, o programa "A união faz a vida", que consiste em construir e vivenciar atitudes e valores de cooperação e cidadania por meio de práticas de educação cooperativa.

Essa forma coletiva de trabalhar não atingiu somente os envolvidos no Pacto, mas também os demais produtores rurais e outros cidadãos do município. A estratégia de trabalhar de forma associada foi disseminada entre diversos grupos no interior do município, o que fez a população entender que deveria se unir para buscar o seu próprio desenvolvimento.

A Cooper Fonte Nova é um exemplo do trabalho associativo: foi criada pelos produtores, no contexto desse programa.

\section{Uma Análise Teórica da Iniciativa de Desenvolvimento Local}

Nesta parte do estudo, procura-se interpretar teoricamente o processo da criação e de desenvolvimento do Programa Pacto Fonte Nova como um processo de desenvolvimento local e uma estratégia de sobrevivência 
de pequenos empreendimentos agroindustriais, baseado fundamentalmente nas ações de cooperação e associativismo de um grupo de pequenos produtores rurais, que encontrou na agroindustrialização uma forma de agregação de valor e melhoria das condições de subsistência destes agentes econômicos.

A análise teórica terá dois momentos. No primeiro, procurar-se-á entender o Pacto Fonte Nova como um projeto de desenvolvimento local explicado pela abordagem do desenvolvimento endógeno, ou seja, por um processo de desenvolvimento que teve uma lógica com a mobilização e articulação de um conjunto de lideranças locais e agentes econômicos na tentativa de reversão de uma situação de estagnação econômica de um determinado entorno territorial.

Num segundo momento, procurar-se-á explicar a organização, estruturação e dinamização das atividades produtivas ligadas ao Pacto Fonte Nova, pela formação de uma estratégia competitiva, baseada fundamentalmente na cooperação e no associativismo, que encontra no modelo das estratégias coletivas a sua sustentação teórica.

\section{O desenvolvimento local concebido por meio de um processo endógeno - o Pacto Fonte Nova}

Tenório (2007) define desenvolvimento local como “[...] um processo centrado em um território concreto no qual os protagonistas são uma pluralidade de atores que ocupam determinadas posições no espaço social e que estabelecem relações em função de objetivos e projetos comuns" (p. 105). Destaca, ainda, esse autor, que o processo de desenvolvimento local é facilitado por meio de "[...] decisões concertadas de modo deliberativo entre a sociedade civil, o mercado e o poder público, é a proximidade entre a autoridade pública e a população" (p. 106). Ocorre uma interação entre a sociedade e o Estado, num contexto em que os atores ficam mais próximos e com isso há uma facilidade de adequação em caso de necessidade.

Já para Buarque (2004), "o desenvolvimento local pode ser conceituado como um processo endógeno de mudança, que leva ao dinamismo econômico e à melhoria da qualidade de vida da população em pequenas unidades territoriais e agrupamentos humanos". Esse autor defende que o desenvolvimento local deve utilizar as potencialidades locais, gerando oportunidades sociais, viabilizando a economia local, preservando os recursos naturais e atendendo à qualidade de vida da população local.

Desse mesmo enfoque, Barquero (2001) traz o conceito de desenvolvimento endógeno de uma perspectiva territorial, no qual cada cidade ou região tem um caminho de desenvolvimento, de acordo com as formas de produção e tecnologias utilizadas pelas empresas do local. Essa visão remete ao atendimento das necessidades da população de uma determinada região, por meio da participação da comunidade. Seu objetivo está acima de obter ganhos individuais. Busca o bem-estar social, econômico e cultural de toda a comunidade local. A estratégia de desenvolvimento interfere nos aspectos produtivos e nas dimensões sociais e culturais, que influenciam o bem-estar de toda a sociedade. As pequenas e médias empresas possuem papel importante na abordagem do desenvolvimento endógeno por possuírem flexibilidade e capacidade empresarial e organizacional. O desenvolvimento endógeno é uma estratégia para a ação; com isso, as comunidades locais que têm uma identidade própria tomam iniciativas que as levem ao desenvolvimento. À medida que se fortalecem, essas comunidades conseguem evitar o êxodo de pessoas e empresas para outras localidades.

Com base nesses entendimentos conceituais, é possível analisar o movimento do Programa Pacto Fonte Nova, desenvolvido no município de Crissiumal (RS), que proporcionou uma nova dinâmica em termos de desenvolvimento local.

A população desse município tem como característica ser formada por pequenos produtores rurais, em cuja atividade agrícola predomina a monocultura. O município está afastado dos grandes centros e a população 
possui dificuldade de acesso às cidades próximas devido às precárias condições das estradas. A população tem um histórico de empobrecimento e de migração para os centros urbanos mais próximos.

O Programa Pacto Fonte Nova pode ser interpretado como um movimento típico de um processo de desenvolvimento local (TENÓRIO, 2007) ou endógeno (BUARQUE, 2004; BARQUERO, 2001), uma vez que a sua construção e seu desenvolvimento exigiram a mobilização e articulação do poder público local (prefeitura e Câmara de Vereadores), da sociedade civil (lideranças estratégicas do município) e mercado (produtores rurais, pequenos agroindustriários e consumidores em geral).

O objetivo do programa era viabilizar a permanência dos produtores no meio rural com maior qualidade de vida, por meio da participação de toda a sociedade. Constata-se um processo de desenvolvimento endógeno na medida em que a população se uniu para mudar uma situação de estagnação econômica e de falta de alternativas produtivas para o município.

Os idealizadores do programa buscaram alternativas para melhorar as condições de vida dessa população marginalizada, sobretudo aquela que habitava a área rural, criando alternativas de trabalho por meio de um processo de agregação de valor aos produtos produzidos.

De acordo com Sachs (2004), o emprego e o autoemprego decente são a melhor maneira de atender às necessidades sociais, pois a inserção no sistema produtivo é uma solução definitiva e as oportunidades de trabalho proporcionam a autoestima, instigando o avanço na escala social.

O Pacto Fonte Nova gerou novos empregos, inseriu um número expressivo de produtores rurais numa cadeia produtiva que integrou produção, industrialização e comercialização de produtos numa escala industrial e empresarial, com ganhos mais vantajosos em termos de resultados do negócio. Elevou, também, a autoestima de uma classe social (pequenos produtores rurais) que estava desanimada e sem perspectiva em termos de sobrevivência na atividade rural, uma vez que a produção agrícola não era suficiente para a manutenção das famílias no campo.

Essa ação de mobilização coordenada pelo poder público, inicialmente com algumas entidades "chaves" para a implantação do programa Pacto Fonte Nova, envolveu as organizações representativas dos agricultores, como o Sindicato dos Trabalhadores Rurais e o Sindicato dos Empregadores Rurais, a Emater, apoiadora dessa iniciativa, a Associação Comercial de Crissiumal (ACI), como entidade importante na inserção e na aceitação dos produtos no comércio local, as cooperativas existentes, com o apoio técnico e os órgãos de desenvolvimento, como o Conselho Municipal de Desenvolvimento Econômico e Social. Todas estas instituições se integraram num projeto que tinha na cooperação e no associativismo a base de sustentação para a retomada do desenvolvimento local.

Os organizadores do programa tinham a intenção de criar mecanismos para viabilizar ações que deveriam ser potencializadas em prol do desenvolvimento local. Tais ações foram direcionadas inicialmente à inserção do produtor rural (pequeno e médio) no processo produtivo e na agregação de valor à produção, aumentando a renda familiar e a geração de empregos. Com o passar do tempo e o sucesso do empreendimento na fase inicial, o programa ampliou o seu público-alvo para os agroindustriários que se localizavam na cidade e que também dependiam da produção do campo.

Os idealizadores e coordenadores desse movimento tiveram a inteligência de buscar referências de experiências de outros municípios e estados que desenvolveram processos semelhantes, com o objetivo de aperfeiçoar os processos de desenvolvimento iniciados no município de Crissiumal. Esta busca de novas experiências proporcionou redirecionamentos estratégicos interessantes na condução do programa, como também possibilitou a ampliação do conhecimento e cultura geral dos sujeitos envolvidos com o programa (lideranças, produtores, agroindustriários), na medida em que tiveram a oportunidade de viajar e conhecer realidades desconhecidas até então. 
A ideia inicial era mobilizar a região para desenvolvê-la, pois traria maiores benefícios à população em geral. Isso, no entanto, não foi possível, por divergências de interesses dos municípios vizinhos a Crissiumal. Cada município tinha um foco de preocupação e problemas diferentes que mereciam abordagens de intervenção no processo de desenvolvimento de forma diversa ou particularizada. Essa constatação levou as lideranças do município de Crissiumal a moverem esforços integrados numa perspectiva mais local, mais restrita ao município de Crissiumal.

A abordagem do desenvolvimento local, segundo Barquero (2001), deve contemplar o objetivo do desenvolvimento sustentável e duradouro, razão por que devem integrar as dimensões econômica, social e ambiental. Iniciativas, dessa ótica, devem conciliar a eficiência na alocação dos recursos públicos e privados, a equidade na distribuição da riqueza e do emprego e o equilíbrio em termos de preservação e cuidado com o meio ambiente.

Nessa ótica de desenvolvimento, o Pacto Fonte Nova nasceu como um programa que tinha como propósito a disseminação de inovações; aproveitar a capacidade empresarial existente; qualificar os produtores, integrando-os ao comércio local; atentar para a conservação do meio ambiente e recuperar a história e a cultura do seu povo, que tinha uma vocação agrícola.

O programa Pacto Fonte Nova teve como compromisso implantar um modelo de desenvolvimento rural sustentável, que levasse os pequenos proprietários rurais a progredirem em suas atividades agroindustriais com eficiência econômica, agregando renda e gerando condições dignas de vida na propriedade rural (PACTO FONTE NOVA, 2007).

O programa foi fruto de uma ação gestora orientada por princípios de mudança e desenvolvimento num determinado território (FISCHER, 2002), na medida em que houve um grande engajamento dos agentes de desenvolvimento local (poder público, mercado e sociedade civil organizada), em torno de um projeto alternativo e solidário, em que valores como qualidade de vida, inclusão de setores marginalizados e obtenção de resultados coletivos estavam presentes na estratégia gestada pelos organizadores do Pacto.

Os componentes principais das iniciativas de desenvolvimento local são, segundo Llorens (2001), o desenvolvimento mais equilibrado territorialmente, com o incentivo de iniciativas de desenvolvimento local e geração de emprego e renda para enfrentar pobreza e marginalização; criação de entornos institucionais econômicos, sociais, políticos e culturais para impulsionar o desenvolvimento do potencial local, compreendendo difusão de inovações; reorganização das bases empresariais e aprimoramento de infraestruturas básicas; e capacitação de recursos humanos e criação de sistemas de informações locais.

Todos esses componentes apontados por Llorens (2001) estão presentes no movimento que deu origem ao Pacto Fonte Nova. No que tange ao desenvolvimento mais equilibrado territorialmente, gerando emprego e renda para enfrentar a marginalização daquela parcela de produtores rurais anteriormente marginalizados, constata-se o aumento de mais de 18\% nos produtores rurais ativos entre os anos de 1997 a 2007; o índice de renda cresceu 3,08\% pelos dados oficiais (FUNDAÇÃO DE ECONOMIA E ESTATÍSTICA, 2010); e se criou emprego para 165 trabalhadores diretos nas agroindústrias, além dos demais agentes que fornecem os produtos para estas. $\mathrm{O}$ aumento de renda se deve à agroindustrialização dos produtos, que gerou maiores ganhos aos produtores.

Houve a difusão de inovações e novos conhecimentos com o processo de agroindustrialização dos produtos. Em razão do surgimento das agroindústrias, criaram-se entornos produtivos dinamizadores da economia local. A Cooper Fonte Nova foi um exemplo dessa iniciativa. Os produtores sentiram necessidade de instituir um instrumento político e organizacional que pudesse viabilizar o entendimento em torno da gestão dos negócios, como também de criar mecanismos de comercialização dos produtos em escala empresarial, para que ela pudesse contribuir nos processos de compra de insumos e intermediação dos negócios. 
O programa impulsionou o processo de melhoria das condições de vida daquela população. Melhorou, por exemplo, os índices na área da saúde, da educação, do saneamento, bem como o Índice de Desenvolvimento Socioeconômico (IDESE) do município, como foi constatado anteriormente.

No que tange à capacitação dos recursos humanos e sistemas de informações locais, cabe citar os treinamentos, realizados pela Emater, dos produtores nas áreas de fabricação e industrialização dos produtos; as parcerias com a Associação Comercial, Senar e Sicredi, nos treinamentos na área de gestão e empreendedorismo; os treinamentos, realizados pelos técnicos das entidades (prefeitura, cooperativas, Emater), dos agroindustriários; a adequação às normas sanitárias e das instalações e embalagens. E, também, a Cooper Fonte Nova repassava constantemente informações sobre a forma legal de produzir e comercializar os produtos dos agroindustriários.

Brum e Müller (2008) têm destacado que as ações de unir as forças dos agentes locais a fim de investir nas localidades e transformá-las em um ambiente apto ao desenvolvimento é uma ideia recente que deve ser perseguida. Eles entendem que existe a necessidade de direcionar ações de políticas públicas e privadas para incentivar o processo de desenvolvimento local. Os projetos e políticas de desenvolvimento, no entanto, devem considerar as peculiaridades locais, atentando para o aspecto de que a agricultura é a principal característica em várias regiões brasileiras, portanto deve-se desenvolver a cadeia produtiva da região e agregar valor ao que é produzido.

Com o Pacto Fonte Nova houve a união de lideranças do município, entre elas o poder público, a Associação Comercial, Emater, sindicatos, cooperativas, os chamados agentes locais (BRUM e MÜLLER, 2008), que direcionaram suas ações, por força do desenvolvimento de políticas destinadas aos pequenos produtores rurais, o que lhes possibilitou novas alternativas de trabalho e renda e provocou um processo de desenvolvimento local.

$\mathrm{O}$ estudo constatou que a agricultura de Crissiumal encontrava-se num estágio de monocultura. O Pacto Fonte Nova proporcionou uma transformação das atividades com a criação e desenvolvimento de várias agroindústrias nos mais diversos setores, atendendo ao aspecto do desenvolvimento da cadeia produtiva e agregação de valor de que tratam Brum e Müller (2008). É o que se chama de reversão da matriz produtiva: antes calcada na monocultura, foi transformada, depois da implantação do Pacto, em uma economia diversificada. Fato constatado pelo número de agroindústrias criadas e ampliadas, sendo mais de 30 empreendimentos com diversificação de atividades, desenvolvidas em razão do Pacto, como as agroindústrias de frango caipira, cachaça orgânica, melado, conservas, embutidos, charque suíno, sucos de polpa de frutas, floricultura, entre outras. Os produtos gerados por essas agroindústrias passaram a fazer parte da mesa dos crissiumalenses, antes vindos, na sua grande maioria, de outros municípios. Em consequência, o setor de serviços ampliou seu campo de atuação, desenvolveu o turismo e o lazer, foram criados e ampliados hotéis, cabanas, trilhas, restaurantes, diversificando as opções de geração de renda e emprego.

Fischer (2002) tem afirmado que os protagonistas das ações de desenvolvimento, na perspectiva do local (de um determinado território), são governos, empresas, comunidades organizadas em redes produtivas, configurando o chamado "entorno territorial inovador". A ação desenvolvida em Crissiumal, por meio do Pacto Fonte Nova, que mobilizou o poder público (governo), fez surgir mais de 30 novos empreendimentos agroindustriais e a integração com o comércio existente no município (empresas). Criou, também, uma rede produtiva de produtos agrícolas, envolvendo as atividades de produção, industrialização e comercialização, no contexto de uma cadeia produtiva (rede produtiva), que integrou produtores e agregou valor aos produtos, aumentando a renda nas propriedades rurais. Estabeleceu, sem dúvida, um "entorno territorial inovador", na medida em que esse movimento proporcionou uma nova dinâmica produtiva e melhoria das condições da população daquele território. 
Estabeleceu-se uma nova situação, tanto econômica - com novas possibilidades de produção, incorporação de tecnologias de produção e canais alternativos de comercialização e distribuição desses produtos agrícolas - quanto social - melhoria das condições de vida das famílias envolvidas, ao proporcionar novos ganhos e criar condições de fixação de pessoas no campo e abertura de novos postos de trabalho e ocupação das pessoas que anteriormente estavam sem alternativas de emprego. Foi, portanto, uma ideia inovadora que trouxe grandes benefícios àquele segmento da população do município de Crissiumal que se encontrava numa situação de estagnação e de poucas alternativas de sobrevivência.

Essa mesma autora, ao estabelecer um contraponto entre os dois sentidos de desenvolvimento - a orientação para a competição e a orientação para a cooperação ou solidariedade -, enfatiza que esta segunda vertente inspira-se em valores de qualidade de vida e cidadania, ou seja, na possibilidade de inclusão de setores marginalizados na produção e usufruto dos resultados. Esse processo de desenvolvimento local desencadeado pelo Pacto Fonte Nova vem ao encontro dessa perspectiva. A preocupação com a qualidade de vida daqueles produtores rurais e da população em geral do município sempre foi o mote central dessa iniciativa de desenvolvimento. A ideia era criar condições para que a população do município de Crissiumal pudesse ter melhor qualidade de vida na medida em que fosse encontrada uma alternativa econômica que possibilitasse maior geração de renda.

Também a preocupação com a cidadania - em termos de inclusão dos pequenos produtores rurais, progressivamente excluídos da atividade agrícola por força de um modelo cuja única alternativa era a produção de soja, que se mostrava inviável às pequenas propriedades rurais - balizou as decisões de idealizar um projeto de desenvolvimento que possibilitasse a reversão de uma situação de quase expulsão dos produtores da atividade agrícola, para uma situação de inclusão destes na dinâmica produtiva do setor com usufruto dos resultados. Ou seja, esse processo de agroindustrialização, gestado em forma cooperada e associativa, contemplou a ideia de uma proposta de desenvolvimento econômico, buscando agregação de valor, produzir produtos competitivos no mercado, profissionalizar a comercialização. Desenvolveu-se, desse modo, numa perspectiva de gestão estratégica, mas com limites da lógica da cooperação e da distribuição dos resultados no contexto dos princípios cooperativistas. A criação da Cooper Fonte Nova foi uma prova dessa filosofia de produção e distribuição dos resultados. Por meio do trabalho cooperativo foram viabilizados os processos produtivos e de comercialização, com ganhos coletivos.

\section{A lógica da cooperação e associativismo como estratégia competitiva sustentável}

Em contraposição às orientações que sustentam concepções de que as organizações, via de regra, são vistas como inimigas dentro de um ambiente altamente competitivo e voraz, que quase sempre levam as organizações a adotarem posições estratégicas de enfrentamento, visando à sobrevivência e à obtenção de vantagens competitivas, aparecem os postulados da colaboração e cooperação como alternativa a uma nova política de negócios (ASTLEY, 1984; BALESTRIN e VERSCHOORE, 2008).

Essa concepção de colaboração, associativismo e cooperação transformou os conceitos de competição em cooperação, de organizações únicas em grupo de organizações e de separação em união, destacando o conceito de estratégias coletivas como a atividade de formação conjunta de políticas e implementação de ações pelos membros de coletividades interorganizacionais. Essas estratégias refletem a necessidade de as organizações promoverem ações de cooperação e associação para lidar com suas naturais interdependências dinâmicas.

O Pacto Fonte Nova foi concebido e se estruturou exatamente no contexto dessa concepção de cooperação e associativismo como estratégia para potencializar as interdependências dinâmicas do setor rural do município de Crissiumal, que estava vivenciando um processo de estagnação e consequente exclusão de uma determinada população - os pequenos produtores rurais. 
A proposta do programa foi centrada no objetivo do resgate das potencialidades locais no ramo agroindustrial, atividade que fazia parte da vocação do município. Procurou-se, assim, mobilizar e articular um grupo de pequenos produtores rurais, por meio de um processo integrado e associativo, para criar condições objetivas de agregação de valor aos produtos do campo e estabelecer uma nova dinâmica produtiva e de comercialização que garantisse a sobrevivência e permanência das pessoas no campo, além de oportunizar possibilidades de competitividade desses produtos no mercado. É nesse contexto que surge a criação da Cooper Fonte Nova como um importante instrumento político e econômico que deveria organizar e unir os produtores e criar condições objetivas para a eficiente produção e comercialização dos produtos no mercado competitivo. Isso se faria por meio de uma grande estratégia coletiva, cuja premissa era encontrar alternativas de sobrevivência de um segmento que enfrentava sérias dificuldades de sustentabilidade e, ao mesmo tempo, preparar esses produtores para competirem no mercado.

Na adoção de estratégias coletivas, para Balestrin e Verschoore (2008), as empresas conseguem alcançar e sustentar diferenciais competitivos por meio das seguintes vantagens: a) aprendizado mútuo no desenvolvimento de novos produtos e processos; b) coespecialidade na exploração de novos nichos de mercado; c) melhor fluxo de informações, promovendo ganhos com as experiências dos parceiros e redução dos níveis de incertezas; e d) economias de escala, na medida em que desenvolvem ações conjuntas que reduzem custos e potencializam o uso dos recursos.

Todas essas vantagens foram percebidas com a união e cooperação das agroindústrias no Programa Pacto Fonte Nova e em torno da Cooper Fonte Nova.

O trabalho coletivo proporcionou aprendizado mútuo, uma vez que os agroindustriários do Pacto conheceram outras propriedades em locais diferentes; visitaram feiras; fizeram cursos de capacitação em processos de produção, como, por exemplo, na linha de sucos, bolachas, conservas, hortaliças; tomaram conhecimento de novos processos de fabricação, como os da área de embutidos e bebidas lácteas; participaram de treinamentos para o atendimento de visitantes ou para a conservação do meio ambiente, entre outros.

As estratégias coletivas adotadas pelos agroindustriários viabilizaram a coespecialidade, abrangendo novos mercados, como é o caso da cachaça orgânica, comercializada dentro e fora do país; dos embutidos, com produtos diferenciados como o charque suíno com menor quantidade de sal; o frango caipira; entre outros. A cooperação entre os agroindustriários proporcionou a comercialização dos produtos em feiras da região e feiras de grande porte como a Expointer (RS), totalizando um percentual significativo das vendas efetuadas pelas agroindústrias, abrangendo um novo mercado, que não existiria sem a colaboração de todos os agroindustriários.

As informações sobre recursos, gestão, procedimentos técnicos, entre outros, são disponibilizadas pela cooperativa para todos os associados, nas reuniões, no atendimento na cooperativa ou nas visitas dos colaboradores da cooperativa aos seus associados. Nos treinamentos ofertados pela cooperativa, em convênio com outras entidades, também ocorre troca de informações, baseada nas experiências relacionadas a produção, processos de comercialização e novas tecnologias de produção, gerando ganhos mútuos.

A economia de escala reflete-se nas participações conjuntas em feiras, por parte dos agroindustriários, quando um agroindustriário comercializa seu produto e dos demais; na diminuição de custos, quando dividem o frete para participarem das feiras; quando recebem a visita de excursões; na aquisição de embalagens em conjunto; quando participam de licitações para comercialização de seus produtos; no marketing de seus produtos, tanto nas palestras quanto na exposição dos produtos nas feiras ou nas prateleiras dos supermercados; na orientação técnica, que é disponibilizada a todos os agroindustriários envolvidos no programa; na aquisição de matéria-prima para produção, como o leite para a bebida láctea, queijo, leite pasteurizado, ou na aquisição de verduras, legumes, cana-de-açúcar e frutas de várias famílias produtoras, por parte das agroindústrias de conservas, melado, geleias e sucos. 
Para Bengtsson e Kock (2000), coopetição refere-se a relacionamentos diádico e paradoxal, que surgem quando várias organizações cooperam em algumas atividades, em forma de aliança estratégica e, em outros momentos, essas mesmas empresas competem entre si em outros campos.

O sistema coopetitivo reflete-se no Pacto Fonte Nova, na forma da criação da Cooper Fonte Nova, que possibilitou a comercialização de produtos com a prefeitura, aproveitando a utilização dos recursos de programas federais, levando a que esses recursos permanecessem no município e favorecessem toda a população.

Esse sistema coopetitivo possibilitou o estreitamento dos relacionamentos entre os agroindustriários, proporcionando novas alternativas de negócios. É o caso da participação em conjunto dos empresários em feiras e exposições, nas quais comercializam seus produtos de forma coletiva. A Cooper Fonte Nova, dentro desse sistema de coopetição, criou laços de interdependência entre os agroindustriários, que buscaram atingir objetivos mútuos (coletivos). Assim, muitos empresários foram beneficiados com computadores e internet, como também em relação à marca Fonte Nova da seguinte forma: uma agroindústria reforça a qualidade dos seus produtos e, ao mesmo tempo, faz a divulgação para benefícios das demais empresas, uma vez que todas possuem a mesma marca. Os aspectos legais e tributários são disseminados a todos os agroindustriários, levando-os a se manterem atualizados e dentro das normas legais.

Por outro lado, as agroindústrias competem entre si, cada uma buscando o seu espaço no mercado, afinal muitas desenvolvem as mesmas atividades e, por sua vez, procuram qualificar os seus processos produtivos e produtos de forma a melhor competir no mercado.

As estratégias coletivas adotadas pelo Pacto em conjunto com a Cooper Fonte Nova proporcionaram aos agroindustriários treinamentos técnicos tanto nos processos de produção quanto na gestão de seus negócios. Essa forma coletiva permite diminuir os custos, por exemplo, na participação em feiras para a comercialização dos produtos: as empresas dividem o transporte e o espaço de comercialização, um comercializa o produto do outro, há revezamento na participação nas feiras e, independentemente da presença da empresa, todos os produtos das agroindústrias são comercializados.

Em razão dessas estratégias coletivas, os agroindustriários tiveram a oportunidade de se transformar em empresários mais bem informados e com melhores possibilidades de sobrevivência no mercado. Certamente se adotassem uma forma isolada de ação isso não aconteceria.

Entre as estratégias coletivas está a mudança cultural em trabalhar de forma cooperada, pois grande parte das empresas não está acostumada a trabalhar em conjunto (CARSTENS e MACHADO-DA-SILVA, 2006). O Pacto fez um trabalho forte e exaustivo no início do programa e continua até o presente momento, para que os agroindustriários trabalhem de forma cooperada, buscando resultados melhores para todos. Isso se reflete na participação em conjunto nas feiras, nos cursos e treinamentos, tanto na área de gestão quanto nos programas específicos para o desenvolvimento das atividades de cada agroindústria, como, por exemplo, na melhoria de seus produtos no setor de higiene, de embalagem, de comercialização e marketing.

Batalha (2001) destaca que o associativismo e as parcerias são fatores importantes para que um produtor obtenha uma renda mínima, pois racionalizam o trabalho e os custos e permitem que o produtor se insira e permaneça no mercado.

Nessa mesma linha de análise, Megido e Xavier (2003) enfatizam que as cooperativas são fonte de divulgação dos produtos e facilitadoras de acordos entre produtores e comerciantes.

A Cooper Fonte Nova constitui-se numa estratégia de sucesso adotada pelos idealizadores do Pacto. É a responsável pela intermediação da comercialização dos produtos dos agroindustriários. Se ela não existisse várias agroindústrias teriam dificuldades de realizar a comercialização dos seus produtos devido às exigências fiscais e legais nesses processos, que são supridas pelo modo cooperado de trabalhar. Além disso, 
a Cooper Fonte Nova proporciona divulgação gratuita aos associados, o que impulsiona a comercialização dos produtos desses empreendimentos. Essa divulgação acontece por meio da participação de representantes da Cooper em feiras, assim como em palestras em associações comerciais, câmaras de vereadores e em diversas entidades governamentais. Ela presta consultoria às agroindústrias tanto na produção de alimentos, na medida em que dispõe de nutricionistas e assistentes sociais, quanto na comercialização dos produtos, por meio da compra de matéria-prima e revenda dos próprios produtos produzidos pelos agroindustriários, participação em licitações, entre outros. A Cooper Fonte Nova é constituída e gerida pelos associados, assim são os mesmos os interesses da cooperativa e dos associados, numa relação de convergência e união em prol do crescimento dos negócios.

A participação em feiras pelos empresários levou alguns empreendimentos a se destacarem internacionalmente, como é o caso da Agroindústria Colônia Nova, indústria produtora de cachaça orgânica. Os agroindustriários visitaram feiras na Alemanha, adequaram-se às normas internacionais, obtiveram a certificação e atualmente comercializam seus produtos para vários países, além do mercado interno. Essa participação em feiras, portanto, gerou novos negócios e foi decisiva para a ampliação e prospecção de novos mercados. Não fosse esse espírito cooperativo e competitivo ao mesmo tempo, certamente os negócios não teriam a amplitude e o sucesso alcançados.

Também é possível caracterizar o Pacto Fonte Nova como um arranjo produtivo local (CASSIOLATO e LASTRES, 2002), visto que se constitui de um sistema produtivo industrial local organizado ao longo de uma filiére, isto é, surgimento de atividades correlacionadas "para frente" e "para trás" da cadeia produtiva. As ligações entre as pequenas agroindústrias, tanto nos aspectos ligados à produção e comercialização de produtos, quanto à sua forma de organização e gestão, fez surgir um sistema institucional mais completo, especializado na atividade de industrialização de produtos agrícolas, demandante de mão de obra local qualificada e responsável pelo estabelecimento de laços mais fortes entre as empresas agroindustriais e demais instituições do município, de modo a criar uma identidade local favorável à cooperação, à solidariedade e à reciprocidade na comunidade.

\section{Conclusões e Considerações Finais}

O objetivo neste estudo foi analisar e compreender o processo de criação e desenvolvimento do Pacto Fonte Nova e as relações deste empreendimento com o desenvolvimento local e regional, buscando descrever o processo de sua criação e evolução com base em sua estruturação e posicionamento no mercado, na condição de um modo de produção associativo.

Conclui-se que, diante da constatação do êxodo rural, de um processo de estagnação e de exclusão de parcela da população (os pequenos produtores rurais), as lideranças locais do município de Crissiumal mobilizaramse para reverter este quadro. Foi possível verificar que o desenvolvimento desse programa foi conduzido de forma competente pelas entidades estratégicas do município, em especial pelo poder público da época, que foi o grande articulador do projeto.

As estratégias empregadas direcionavam-se inicialmente a alternativas para uma faixa da população mais marginalizada, os pequenos produtores rurais, no caso. O programa foi bem-estruturado, com a criação de legislação específica, formação de uma coordenadoria executiva e constituição de uma estrutura técnica para dar suporte ao desenvolvimento das atividades. Os idealizadores do programa sempre primaram pela participação ativa de todos os envolvidos, principalmente das entidades promotoras e dos agroindustriários, demonstrando uma forma cooperada de trabalhar. Em termos de promoção do desenvolvimento, o programa buscou alternativas locais, demonstrando uma experiência de desenvolvimento endógeno, com a criação de novos empreendimentos econômicos, agregação de renda e melhoria na qualidade de vida da população, 
sobretudo daquela que participou do programa e, por extensão, de toda a comunidade que se beneficiou com os resultados dessa iniciativa de desenvolvimento.

O modo de produção associativo desenvolvido resgatou uma cultura de trabalho cooperado que fez surgir um conjunto de novas atividades agrícolas, proporcionando a diversificação de atividades e, por consequência, a estagnação do êxodo rural e a agregação de mais renda às pequenas propriedades rurais que se encontravam em situação difícil. De outra parte, também proporcionou um reequilíbrio em termos de dinâmica dos demais setores do município, na medida em que foram beneficiadas com melhorias as áreas da saúde, transporte, educação, emprego, infraestrutura, saneamento, entre outras.

A união das entidades foi um fator importante para a concretização do Pacto Fonte Nova. O programa, como já foi dito, nasceu de um projeto político cujo propósito era encontrar uma alternativa econômica para o município, mas também se constituiu num projeto social, na medida em que mobilizou lideranças e pessoas num processo de qualificação profissional e conscientização da necessidade de somar forças e empreender a solidariedade em prol de um grande objetivo comum - a melhoria das condições de vida da população.

Percebe-se que o Pacto Fonte Nova foi uma iniciativa interessante de desenvolvimento local por meio de um processo de articulação das lideranças e das forças econômicas e políticas do município de Crissiumal, que se encontrava num processo de estagnação econômica e de inércia em termos de alternativas que pudessem reverter o quadro de descrédito e desânimo da população. Aquele que foi, então, um projeto de revitalização do desenvolvimento local e que proporcionou uma nova dinâmica de entendimento dos agentes políticos e econômicos do município também apresentou uma série de problemas e entraves que dificultaram um resultado ainda mais expressivo dessa iniciativa de desenvolvimento local, concebida mediante uma ação centrada no propósito da cooperação, da solidariedade e do associativismo.

Em termos de problemas e entraves apresentados, dois aspectos merecem destaque. O primeiro se refere ao despreparo das pessoas para trabalhar de forma associativa. $\mathrm{O}$ modelo de desenvolvimento capitalista - no qual a concorrência é uma tônica e cada indivíduo procura acumular capital, estar à frente do outro apareceu como um dos primeiros obstáculos a serem superados para a efetivação do projeto.

Uma das condições para que um projeto de produção agroindustrial obtenha êxito é a garantia da oferta de produtos em quantidade e qualidade que atendam as necessidades do público consumidor, com certa regularidade e continuidade. Essa condição somente se viabiliza se o trabalho dos produtores for conduzido de forma profissional e com amplo entendimento entre eles. Diante dessa exigência, portanto, a formação do capital social naquele projeto - entendido como a capacidade de cooperação em uma dada sociedade, num conjunto de interações sociais e na soma de esforços baseados na confiança mútua e na capacidade de resolver conflitos de forma democrática - era uma condição chave para que se pudesse avançar em termos de resultados.

O associativismo requer ação solidária: os interesses da coletividade devem preponderar sobre os individuais. Não obstante o investimento em programas de formação no campo do associativismo, promovidos pela organização do Pacto e pela cooperativa, muitos dos problemas identificados nas lideranças do Pacto e nas agroindústrias devem-se ao individualismo das pessoas. Característica que aparece tanto nas disputas por espaços no campo político quanto no econômico. A disputa de poder identificada em vários momentos da constituição do Pacto entre as lideranças - como também nas ações de produção, comercialização e distribuição dos produtos oriundos das agroindústrias integrantes - sempre esteve presente nas diferentes fases do programa, constituindo-se em um dos entraves para certa desarticulação desse movimento que começou bem e que se encontra atualmente numa fase de estagnação.

$\mathrm{O}$ segundo aspecto a ser apontado em termos de problema no desenvolvimento do programa refere-se à descontinuidade nos projetos políticos dos governos. Em nível estadual, no ano de 1999, foi instituído um programa de incentivo às iniciativas de agroindustrialização no âmbito da agricultura familiar, como forma 
de desenvolvimento de um setor que historicamente sempre foi excluído das políticas públicas. Porém, quando o governo do estado mudou, os incentivos foram extintos, com prejuízos enormes para a continuidade daqueles empreendimentos agroindustriais que estavam integrados a esse programa estadual.

No ano de 2009, a mudança do governo municipal teve efeitos na gestão do Programa Pacto Fonte Nova. Com o início das atividades do novo governo municipal, alguns funcionários da prefeitura foram desligados e outros transferidos de setor, o que teve consequências diretas nas atividades do Pacto. Muitos processos administrativos interrompidos ocasionaram a suspensão de projetos que eram beneficiados com recursos de órgãos federais em apoio ao Pacto Fonte Nova.

A partir do ano de 2010, já com a devida adaptação dos novos funcionários e técnicos da nova administração pública, existe a expectativa de retomar a articulação com órgãos do governo federal para reforçar a cota de recursos a ser destinada aos incentivos dos empreendimentos do Pacto Fonte Nova.

Esses processos de descontinuidade das administrações sempre prejudicam os projetos em andamento. Com o Pacto Fonte Nova a história se repetiu. A transição de uma administração para outra ocasiona mudança de política e interrupção de ações no campo das políticas públicas e dos projetos de desenvolvimento. Por mais que seja um projeto de interesse da sociedade local, com o envolvimento de vários segmentos, independentemente das correntes políticas existentes no município, a mudança das lideranças que estão à frente dos governos e instituições estratégicas locais traz consigo alterações de estratégias e comportamentos.

O Pacto Fonte Nova teve uma influência muito forte da liderança do ex-prefeito Walter Luiz Heck, o grande mentor e articulador deste projeto de desenvolvimento local. A saída deste líder e as consequentes alterações nas coordenações que envolviam as diferentes organizações e instituições participantes do Pacto tiveram como resultado evidente o enfraquecimento desse movimento.

O sucesso de um processo de desenvolvimento local exige articulações e decisões concertadas entre a sociedade civil organizada, o mercado e o poder público. O Pacto Fonte Nova constituiu-se num projeto que buscou a articulação dessas três instâncias, apresentando avanços significativos em termos de alternativas socioeconômicas para aquele município, como também mostrou as dificuldades de conciliação de interesses nessas esferas, comprovando que o desenvolvimento é um processo complexo em razão das relações sociais a ele inerentes.

Resta dizer que este estudo limitou-se a contar a história dessa iniciativa de desenvolvimento local, indicando seus avanços e problemas, no contexto da lógica da cooperação e da solidariedade como estratégia de desenvolvimento. A descrição e a análise do processo de criação e desenvolvimento desse programa e, consequentemente, do seu impacto no desenvolvimento local, foram realizadas com base na percepção dos seus idealizadores e gestores, como também dos agentes envolvidos, restringindo-se, portanto, às percepções e interpretações destes sujeitos.

Em termos de continuidade de estudos no campo do desenvolvimento local, as conclusões do presente estudo permitem sugerir a utilização de uma abordagem de pesquisa quantitativa para a análise desse programa de desenvolvimento, isto é, que seja possível dimensionar por meio de indicadores (qualidade de vida, crescimento econômico, desenvolvimento humano) o real impacto socioeconômico do programa para o município.

Sugere-se, também, um estudo que possa explorar um aspecto identificado e não muito explorado neste estudo: as dificuldades do desenvolvimento das formas participativas de gestão em projetos de desenvolvimento local. Ou seja, os problemas e dificuldades de levar adiante uma proposta de ação coletiva que exige participação, envolvimento e espírito cooperativo de um conjunto de agentes com interesses individuais e particulares diferenciados, que necessita unir forças em prol do interesse comum. 


\section{Referências}

ASTLEY, W. G. Toward an appreciation of collective strategy. Academy of Management Review, v. 9, n. 3, p. 526$535,1984$.

; FOMBRUN, C. J. Collective strategy: social ecology of organizational environments. Academy of management Review, v. 8, n. 4, p. 576-587, 1983.

BALESTRIN, A.; VERSCHOORE, J. Redes de cooperação empresarial: estratégias de gestão na nova economia. Porto Alegre: Bookman, 2008.

BARQUERO, A. V. Desenvolvimento endógeno em tempos de globalização. Porto Alegre: Fundação de Economia e Estatística, 2001.

BATAlHA, M. O. Gestão agroindustrial: Gepai - Grupo de Estudos e Pesquisas Agroindustriais. 2. ed. São Paulo: Atlas, 2001.

BENGTSSON, M.; KOCK, S. Coopetition in business networks to cooperate and compete simultaneously. Industrial Marketing Management, v. 29, n. 5, p. 411-426, 2000.

BRUM, A. L.; MÜLLER, P. K. (Org.). Aspectos do agronegócio no Brasil: a realidade na primeira década do terceiro milênio. Ijuí: Ed. Unijuí, 2008.

BUARQUE, S. C. Construindo o desenvolvimento local sustentável. Rio de Janeiro: Garamond, 2004.

CARSTENS, D. D. S.; MACHADO-DA-SILVA, C. L. Estratégia e estrutura de relacionamentos na rede de Empresas Alpha. In: ENCONTRO ANUAL DA ANPAD, 2006, 23 a 27 setembro, Salvador. Anais... Rio de Janeiro: Associação Nacional de Programas de Pós-Graduação em Administração, 2006.

CASSIOLATO, J. E.; LASTRES, H. M. M. O enfoque em sistemas produtivos e inovações locais. In: FISCHER, T. (Org.). Gestão do desenvolvimento e poderes locais: marcos teóricos e avaliação. Salvador, BA: Casa da Qualidade, 2002.

FISCHER, T. (Org.). Gestão do desenvolvimento e poderes locais: marcos teóricos e avaliação. Salvador: Casa da Qualidade, 2002.p. 61-90.

FUNDAÇÃO DE ECONOMIA E ESTATISTICA. Disponível <http://www.fee.tche.br/sitefee/pt/content/estatisticas/pg_idese_municipio_classificacao_idese.php?ano=2006\&letra=C \&ordem=municipios $>$. Acesso em: 11 maio 2010.

GUERREIRO RAMOS, A. A nova ciência das organizações - uma reconceituação da riqueza das nações. Rio de Janeiro: Ed. da Fundação Getulio Vargas, 1981.

HABERMAS, J. Consciência moral e agir comunicativo. São Paulo: Brasiliense, 1989. INSTITUTO BRASILEIRO DE GEOGRAFIA E ESTATÍSTICA. Disponível em: <http://www.ibge.gov.br/home/estatistica/populacao/contagem2007/default.shtm>. Acesso em: 04 fev. $2010 \mathrm{a}$.

LLORENS, F. A. Desenvolvimento econômico local: caminhos e desafios para a construção de uma nova agenda política. Rio de Janeiro: BNDES, 2001.

MEGIDO, J. L. T.; XAVIER, C. Marketin e Agribusiness. São Paulo: Atlas, 2003.

MERRIAM, S. B. Qualitative research and case study applications in education. San Francisco, CA: Jossey-Bass, 1998.

MINTZBERG, H. Patterns in strategy formation. Management Science, v. 24, n. 9, p. 934-948, maio 1978. 

Sage, 1983.

. An emerging strategy of "direct research". In: VAN MAANEN, J. (Ed.). Qualitative Methodology. London:

. Crafting strategy. Harvard Business Review, p. 66-75, jul./ago. 1987.

. An emerging strategy of “direct research”. Administrative Science, v.24, n.9, p.582-589, 1997.

.; AHLSTRAND, B.; LAMPEL, J. Safári de estratégia: um roteiro pela selva do planejamento estratégico. Porto Alegre: Bookman, 2000.

197.

; McHUGH, A. Strategy formation in an adhocracy. Administrative Science Quarterly, v. 30, 1985, p. 160-

.; QUINN, J. B. O processo da estratégia. Porto Alegre: Bookman, 2001.

MOTTA, P. R. Administração para o desenvolvimento: a disciplina em busca da relevância. In: CAIDEN, G. E.; CARAVANTES, G. R. Reconsideração do conceito de desenvolvimento. Caxias do Sul: Educs, 1985, p.101-115.

NALEBUFF, B. J.; BRANDENBURGER, A. M. Co-opetição. Rio de Janeiro: Rocco, 1996.

PACTO FOnTE NOVA. Programa Municipal de Desenvolvimento Agroindustrial Pacto Fonte Nova. 2007, Trabalho não publicado.

PETTIGREW, A.; FERLIE, E.; McKEE, L. Shaping strategic change. London: Sage, 1992.

.; WHIPP, R. Managing change for competitive success. Oxforf: Blackwell Publishers Ltd. 1991.

PREFEITURA DE CRISSIUMAL. Secretaria da Fazenda, 2010.

SACHS, I. Desenvolvimento: includente, sustentável, sustentado. Rio de Janeiro: Garamond, 2004.

SAUSEN, J. O. Adaptação estratégica organizacional: o caso da Kepler Weber S/A. Ijuí: Ed. Unijuí, 2003.

SIEDENBERG, D. R. Desenvolvimento: ambigüidades de um conceito difuso. Revista Desenvolvimento em Questão, n. 3. jan./jun. 2004, do Programa de Pós-Graduação em Desenvolvimento, Gestão e Cidadania, UNIJUI, 2004. 2006.

. Cidadania. In: SIEDENBERG, D. R. Dicionário desenvolvimento regional. Santa Cruz do Sul: EDUNISC,

TENÓRIO, F. G. Tem razão a administração? Ensaios de teoria organizacional. 2. ed. Ijuí: Ed. Unijuí, 2004.

(Org.). Cidadania e desenvolvimento local. Rio de Janeiro: FGV; Ijuí: Ed. Unijuí, 2007.

UNIJUI. Banco de Dados. Gestão Social e Cidadania. 2010. Disponível em: <http://www.projetos.unijui.edu.br/cidadania/gscdados> Acesso em: 19 abr. 2010. 